\title{
Cognition and chronic pain: an analysis on community-dwelling elderly caregivers and non-caregivers
}

\author{
Cognição e dor crônica: uma análise em idosos cuidadores e não cuidadores residentes na \\ comunidade
}

\author{
Marielli TERASSI', Ana Carolina OTTAVIANI', Érica Nestor de SOUZA', Francisco José FRAGA², \\ Pedro MONTOYA ${ }^{3}$, Sofia Cristina lost PAVARINI ${ }^{4}$, Priscilla HORTENSE ${ }^{1}$
}

\begin{abstract}
Background: In recent years there has been an increasing number of elderly people who care for another elderly person in the same household. These elderly people are more susceptible to overload and the presence of chronic pain, while pain can negatively influence cognitive variables. Objective: To compare the performance and cognitive processing of elderly caregivers and non-caregivers with and without chronic pain. Methods: This was a cross-sectional study carried out among 149 elderly people divided into four groups that were matched according to sex, age and schooling. The tests used were a numerical pain assessment scale, the Brief Cognitive Screening Battery (BCSB), Addenbrooke's Cognitive Examination (ACER-R) and cognitive processing through event-related potentials (P300). Results: Statistically significant differences between participants with and without chronic pain were found with regard to attention/orientation ( $p=0.045$ ) and visual-spatial skills ( $p=0.017)$, and in the total score $(p=0.033)$. In the pain-free group, the caregivers showed better results than the non-caregivers. There were no effects between subjects or interactions (caregiving and pain factors) either on P300 amplitude or on P300 latency. Conclusion: In general, it was observed that pain-free individuals presented better performance. No relationship was observed between the factors care and pain regarding cognitive performance.
\end{abstract}

Keywords: Chronic Pain; Cognition; Caregivers; Elderly.

\section{RESUMO}

Introdução: Nos últimos anos, observou-se crescente número de idosos que realizam o cuidado a outro idoso no mesmo domicílio. Esses idosos estão mais susceptíveis à sobrecarga e à presença de dor crônica, sendo que a dor pode influenciar negativamente as variáveis cognitivas. Objetivo: Comparar o desempenho e o processamento cognitivo de cuidadores idosos e não cuidadores com e sem dor crônica. Métodos: Estudo transversal realizado com 149 idosos, divididos em 4 grupos, pareados por sexo, idade e escolaridade. Os testes utilizados foram: escala numérica de avaliação da dor, Bateria Breve de Rastreio Cognitivo (BBRC), Addenbrooke's Cognitive Examination (ACER-R) e processamento cognitivo por meio de Potenciais Relacionados a Eventos (P300). Resultados: Foram encontradas diferenças estatisticamente significantes entre os participantes com e sem dor crônica nos domínios cognitivos atenção/orientação ( $p=0,045)$ e habilidades visual-espacial ( $p=0,017)$, bem como no escore total do instrumento ACE-R $(p=0,033)$. No grupo sem dor foram encontradas diferenças estatísticas entre cuidadores e não cuidadores, com melhores resultados no grupo cuidador. Não houve efeitos entre os sujeitos ou interações (fatores de Cuidado e Dor) na amplitude do P300 ou na latência do P300. Conclusão: De maneira geral, observou-se que indivíduos sem dor apresentaram melhor desempenho. Não foi observada relação entre os fatores cuidado e dor no desempenho cognitivo.

Palavras-chave: Dor Crônica; Cognição; Cuidadores; Idosos.

\footnotetext{
'Universidade Federal de São Carlos, Departamento de Enfermagem, São Carlos SP, Brazil.

¿Universidade Federal do ABC, Centro de Engenharia, Modelagem e Ciências Sociais Aplicadas, Santo André SP, Brazil.

${ }^{3}$ University of Balearic Islands, Research Institute of Health Sciences, Palma, Spain.

«Universidade Federal de São Carlos, Departmento de Gerontologia, São Carlos SP, Brazil.

Marielli TERASSI (D) https://orcid.org/0000-0002-8933-3519; Ana Carolina OTTAVIANI (D) https://orcid.org/0000-0003-4037-4587;

Érica Nestor de SOUZA (DD https://orcid.org/0000-0002-7952-7643; Francisco José FRAGA (D) https://orcid.org/0000-0002-4895-807X;

Pedro MONTOYA (ID https://orcid.org/0000-0001-8652-948X; Sofia Cristina lost PAVARINI (D) https://orcid.org/0000-0001-9359-8600;

Priscilla HORTENSE (D) https://orcid.org/0000-0003-0554-451X

Correspondence: Marielli Terassi; Email:ma_terassi@hotmail.com.

Conflict of interest: There is no conflict of interest to declare.
}

Support: This work was supported by the Coordenação de Aperfeiçoamento de Pessoal de Nivel Superior (CAPES), Conselho Nacional de Desenvolvimento Científico e Tecnológico (CNPq -304067/2015-16) and Fundação de Amparo à Pesquisa do Estado de São Paulo (FAPESP -2017/04129-9).

Authors' contributions: MT contributed to the investigation, collected data, performed statistical analysis and wrote the manuscript; ACO and ENS contributed to the investigation, data collection, writing of the original project; FJF and PM contributed to the investigation, methodology, carried out statistical analysis and supervision; SCIP and PH contributed to the conceptualization, investigation, methodology, supervision and writing of the original project.

Received on February 6, 2020; Received in its final form on April 16, 2020; Accepted on June 1, 2020. 


\section{INTRODUCTION}

Some studies have suggested that chronic pain may compromise cognitive performance, which would thus show that there is a good correlation between brain processing of pain and other cognitive functions ${ }^{1,2}$. Based on these findings, it has been proposed that focusing on pain may be a cumulative process that happens over the years and that this may have a significant impact on cognitive performance regarding daily activities ${ }^{3}$, such as social relationships and caregiving s.5. $^{4}$.

Informal caregivers are defined as people who provide continuous unpaid care, in relation to daily or instrumental activities, for an individual with an illness or chronic disability ${ }^{6}$. The older a caregiver is, the more predisposed this individual may be towards having symptoms of overload and stress and developing pain, due to the task of caring ${ }^{7,8,9}$. In addition, it should be taken into account that there is an increasing number of elderly people who are also taking care of another elderly person in the same household. Among these individuals, the presence of chronic pain associated with poor cognitive performance may negatively interfere with basic and complex activities aimed towards caring for another elderly person ${ }^{10,11,12}$.

Investigation of this topic is crucial because of the scarcity of studies in this area and the need to possibly establish a relation between chronic pain, cognition, aging and the act of caregiving. Assessment of cognitive processing, together with use of standardized neuropsychological evaluation tools, may be an effective way to study the relationship between chronic pain and cognition. It is fundamental to include a group of non-caregivers in the analyses since there are no conclusive studies analyzing the relationship between chronic pain and cognition in the population of elderly caregivers. Therefore, the objective of this study was to compare the performance and cognitive processing of elderly caregivers and non-caregivers with and without chronic pain.

\section{METHODS}

\section{Participants}

The sample consisted of elderly people registered at primary healthcare services in the city of São Carlos, São Paulo, Brazil. A total of 149 individuals participated in the study, divided into four groups: 44 caregivers with chronic pain (CP), 44 non-caregivers with chronic pain (NP), 31 caregivers without pain (CWP) and 30 non-caregivers without pain (NWP). The groups were matched according to sex, age and educational level.

The sample size was calculated based on a pilot study that was conducted among eight elderly caregivers enrolled in primary healthcare units, from which the alpha level of significance at $5 \%$ and the power of the sample at $80 \%$ were established.

\section{Inclusion criteria}

Participants were required to be older than 60 years and to be registered as a resident in an urban or rural area monitored by Family Health Units (FHUs). The individuals selected were divided into two subgroups: caregivers and non-caregivers. To be in the caregiver group, the individual needed to be the primary informal caregiver of another elderly person living in the same house. The person being cared for was required to be dependent in at least one of the basic activities of daily living (BADLs) ${ }^{13}$ and instrumental activities of daily living (IADLs) ${ }^{14}$. The elderly caregiver was also assessed regarding BADLs and IADLs and was required to be more independent than the person being cared for. To be included in the non-caregiver group, the person would need to have not provided any type of care to another elderly person in the last 12 months and would need to be living alone or with a non-elderly family member at the time of the study.

In addition, the subjects were classified according to the presence of chronic pain: caregivers with vs. without chronic pain. To establish the existence of chronic pain, the inclusion criterion was a report of continuous or frequent pain in any body region for a period greater than or equal to six months ${ }^{15}$.

\section{Exclusion criteria}

A preliminary interview was conducted in the first stage of the research and individuals who presented evident severe cognitive deficits, severe hearing problems or histories of stroke, alcoholism or psychoactive drug abuse were excluded.

\section{Data collection procedures}

Data were collected between June 2016 and July 2017 in two stages: In the first stage, previously trained interviewers visited the elderly people who were registered in the FHUs, at their homes, and verified the inclusion and exclusion criteria. If the criteria were met, the individual's caregiver was invited to participate in the study and, after acceptance, the instruments of sociodemographic characterization, health evaluation and care provided were applied. In the second stage, auditory event-related potentials ${ }^{16,17}$ and standardized neuropsychological tests (Brief Cognitive Battery ${ }^{18,19}$ and Addenbrooke’s Cognitive Examination Revised ${ }^{20}$ ) were applied. Among individuals with chronic pain, the variables investigated were the intensity of pain (at the time of the evaluation and in the previous week), number of years with pain and location of pain. All procedures and tests were conducted in a quiet and peaceful environment in a community room, to facilitate participant access.

To collect data, a sociodemographic instrument asking about the variables of gender (female or male), age and years of schooling was used. For the caregiver group, information about the degree of kinship with the elderly person being cared for, the length of time as a caregiver (1-4 years; $5-9$ years; or $\geq 10$ years) and the number of care hours provided per day (1-4 hours; $5-9$ hours; or $\geq 10$ hours) were also collected. 
To evaluate cognitive performance, two standardized neuropsychological tests were used. The Brief Cognitive Screening Battery (BCSB) comprises the domains of visual perception and nomination, incidental memory, immediate memory, learning, verbal fluency (animals), clock design, five-minute memory and recognition, which are evaluated by means of figures presented to participants. In the immediate memory, scores below 5 indicate impaired attention; in the learning memory, the participant is expected to obtain a score of 7 or more; in delayed memory at least 6 points and in recognition memory scores close to $9^{18,19}$. Addenbrooke's Cognitive Examination Revised (ACE-R) evaluates five domains of cognitive functioning. The total score ranges from 0 to 100 and is distributed among the five domains: orientation/attention (18 points), memory (26 points), verbal fluency (14 points), language (26 points) and visual skills (16 points). The higher the score is, the better the cognitive performance is ${ }^{20}$.

To evaluate pain intensity, an 11-point numerical scale $(0$ representing no pain and 10, an unbearable pain) was used. The pain intensity of the last week and the pain intensity at the time of the interview were evaluated (continuous scale). A body diagram was used, in which the participant visually indicated the locations affected by the pain (39 locations) ${ }^{21}$.

The Geriatric Depression Scale (GDS-15) was used to evaluate depression symptoms, with the aim of assessing depression symptoms in the elderly. It is composed of 15 dichotomous "yes" or "no" questions. The score ranges from zero to 15 , where scores from 0 to 5 indicate no depressive symptoms, 6 to 10 mild depressive symptoms and 11 to 15 severe depressive symptom. For the present study, a continuous score was used, such that higher scores indicating more depressive symptoms ${ }^{22}$.

Cognitive processing was also assessed by using eventrelated potentials (ERPs) obtained from electroencephalograms (EEGs). These were run during an auditory oddball task. Three-channel EEGs were recorded on a clinical device (Neurosoft; model Neuron-Spectrum-4/EPM). Electrodes were attached in accordance with the standard 10/20 system, on the frontal $(\mathrm{Fz})$, central $(\mathrm{Cz})$ and parietal $(\mathrm{Pz})$ scalp regions. Reference electrodes were placed on the right (A2) and left (A1) earlobes and were interconnected, as recommended by the American Clinical Neurophysiology Society ${ }^{16}$. In addition, to monitor and subsequently eliminate out-ofbrain artifacts, two additional electrodes (bipolar montage), positioned in the corner of the left eye and over the eyebrow of the right eye, were used to capture eye movements ${ }^{16,17}$.

The task performed by the subject consisted of pressing a button with the dominant hand for each infrequent (target) stimulus detected. An initial training session was given with a presentation of some auditory stimuli, so that the individual understood the examination dynamics and to ensure that all participants understood the task. During the auditory oddball task, 60 infrequent target auditory stimuli (20\% of the times; $2000 \mathrm{~Hz}$ pure tone lasting $100 \mathrm{~ms}$ ) and 240 frequent non-target stimuli ( $80 \%$ of the times; $1000 \mathrm{~Hz}$ ) were randomly presented to the participants every two seconds (inter-stimulus interval). The impedance of all the electrodes was maintained below 5 $\mathrm{K} \Omega$. The EEG data were analyzed offline after baseline correction (100 ms before stimulus onset) and ocular artifacts (eye blinks) were removed using independent component analysis (ICA). Lastly, the EEG data were separately processed for each condition ( frequent vs infrequent stimuli) with the aim of obtaining amplitude and latency measurements of the P300 ERP component for each electrode location. The P300 on the $\mathrm{Fz}, \mathrm{Cz}$ and $\mathrm{Pz}$ channels was detected as the maximum amplitude in the 250-500 ms interval (after stimulus onset) of the wave obtained by subtracting the average of target (infrequent) stimuli from the average of non-target (frequent) stimuli. According to previous data in the literature, higher P300 amplitudes would reflect better cognitive processing and greater attention ${ }^{16,17,23}$. On the other hand, shorter latencies are associated with better information processing ${ }^{23}$.

\section{Ethical issues}

This project was approved by the Ethics Committee for Research on Human Beings of the Federal University of São Carlos, under the number CAAE 51773915.1.0000.5504. All the participants who agreed to participate signed an informed consent form.

\section{Statistical analysis}

Means and standard deviations were calculated to describe the demographic and clinical characteristics of the sample. The chi-square test was used to compare the categorical variables between the groups. Two-way ANOVA with the factors caregiving and pain was used to assess betweensubject effects regarding cognitive performance in the ACE-R and BCSB domains. Levene's test was applied to verify data homogeneity (equality of variances). To assess brain processing (P300 amplitude and latency), repeated-measurements ANOVA with scalp location (Fz, $\mathrm{Cz}$ or $\mathrm{Pz}$ ) as the withinsubject factor and caregiving and pain as the between-subject factors was used. Mauchly's test was applied to check the assumption of sphericity. A significance level of $5 \%$ was adopted for all statistical analyses.

\section{RESULTS}

\section{Sociodemographic, caregiving}

\section{and chronic pain characteristics}

Table 1 shows the characteristics of the participants in each group. The groups were similar regarding gender, age, schooling and characteristics of caregiving and pain. The majority of the participating caregivers had provided care for their spouse for more than 10 years. The most prevalent body locations with pain were the lumbar region and the lower limbs, for both groups. The average number of years of pain was approximately 7 years. 
Table 1. Descriptive statistics on sociodemographic variables (means and standard deviations) among the groups, divided according to caregiving and chronic pain characteristics.

\begin{tabular}{|c|c|c|c|c|c|}
\hline & \multicolumn{2}{|c|}{ Chronic pain } & \multicolumn{2}{|c|}{ Absence of pain } & \multirow[b]{2}{*}{$p$-value } \\
\hline & $\begin{array}{c}\text { Caregiver } \\
(n=44)\end{array}$ & $\begin{array}{c}\text { Non-caregiver } \\
(n=44)\end{array}$ & $\begin{array}{c}\text { Caregiver } \\
(n=31)\end{array}$ & $\begin{array}{c}\text { Non-caregiver } \\
\quad(n=30)\end{array}$ & \\
\hline Female* & $88.6 \%$ & $81.8 \%$ & $74.2 \%$ & $66.7 \%$ & 0.108 \\
\hline Age in years (mean, SD)** & $70 \pm 5.8$ & $71.1 \pm 7.4$ & $68.7 \pm 5.7$ & $71.1 \pm 7.7$ & 0.117 \\
\hline Years of schooling (mean, SD)** & $3.7 \pm 3.2$ & $3.4 \pm 2.8$ & $4.1 \pm 3.5$ & $3.8 \pm 3.2$ & 0.918 \\
\hline \multicolumn{6}{|l|}{ Who is the caregiver?* } \\
\hline Spouse & $90.9 \%$ & & $87.1 \%$ & & \\
\hline Mother/father & $2.3 \%$ & --- & $6.5 \%$ & --- & 0.661 \\
\hline Other & $6.8 \%$ & & $6.5 \%$ & & \\
\hline \multicolumn{6}{|l|}{ Years of caregiving* } \\
\hline $1-4$ & $20.9 \%$ & & $32.1 \%$ & & \\
\hline $5-9$ & $27.9 \%$ & --- & $28.6 \%$ & --- & 0.507 \\
\hline$\geq 10$ & $51.2 \%$ & & $39.3 \%$ & & \\
\hline \multicolumn{6}{|l|}{ Hours of caregiving each day* } \\
\hline $1-4$ & $47.7 \%$ & & $56.7 \%$ & & \\
\hline $5-9$ & $36.4 \%$ & --- & $23.3 \%$ & --- & 0.491 \\
\hline$\geq 10$ & $15.9 \%$ & & $20.0 \%$ & & \\
\hline \multicolumn{6}{|l|}{ 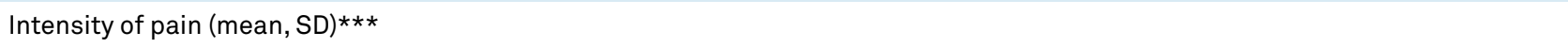 } \\
\hline At the time of the evaluation & $4.9 \pm 2.5$ & $4.8 \pm 2.7$ & --- & --- & 0.964 \\
\hline Previous week & $6.2 \pm 2.6$ & $5.9 \pm 2.4$ & --- & --- & 0.505 \\
\hline Years with pain (mean, SD)*** & $7.5 \pm 7.5$ & $7.0 \pm 7.4$ & --- & --- & 0.502 \\
\hline \multicolumn{6}{|l|}{ Location of pain* } \\
\hline Lumbar region & $63.6 \%$ & $47.7 \%$ & --- & --- & 0.123 \\
\hline Lower limbs & $43.1 \%$ & $50 \%$ & --- & --- & 0.219 \\
\hline Depression symptoms (mean, SD)** & $4.7 \pm 2.9$ & $3.7 \pm 2.6$ & $2.5 \pm 2.1$ & $3.1 \pm 2.8$ & $0.006^{\#}$ \\
\hline
\end{tabular}

*Chi-square test; **ANOVA test; ${ }^{* * * S t u d e n t ' s ~ t-t e s t ; ~}{ }^{*}$ difference between caregivers with chronic pain and caregivers without pain.

Regarding the variable of depressive symptoms, although the average score among the participants was below the cutoff score of the instrument, a statistical difference between the $\mathrm{CP}$ and CWP groups could be seen $(\mathrm{p}=0.006)$, such that the CWP group had a higher score from the instrument (Table 1).

\section{Cognitive performance}

Table 2 shows descriptive statistics on the neuropsychological data obtained using the ACE-R and BCSB instruments in the four subgroups of participants. Equality of variances was confirmed for all the ACE-R and BCSB variables. Regarding ACE-R, a two-way ANOVA test revealed that there were significant differences in the domains of attention/orientation $[\mathrm{F}(1,145)=4.07 ; \mathrm{p}=0.045]$ and visual-spatial skills $[\mathrm{F}(1,145)=5.8$; $\mathrm{p}=0.017]$, and also in the total score $[\mathrm{F}(1,145)=4.61 ; \mathrm{p}=0.033]$, which were due to the pain factor. These findings indicated that individuals without chronic pain presented better cognitive performance than individuals with chronic pain. No effect on cognitive performance was observed from the caregiving factor, as assessed via the ACE-R instrument, and no significant interactions between the caregiving and pain factors were found with regard to any of the ACE-R variables.
The BCSB instrument was used to find out whether there was any difference between the groups in the memory domain. Significant interaction between the caregiving and pain factors was observed, with statistical differences between caregivers and non-caregivers in the group without chronic pain for three of the memory domains: Immediate $[F(1,143)=4.3 ; p=0.040]$, Learning $[F(1,143)=6.2 ; p=0.014]$ and Recognition $[F(1,143)=6.2 ; p=0.041]$, with better results for the caregiver group (Table 2).

\section{Cognitive processing}

Repeated-measurement ANOVA at the $\mathrm{Fz}, \mathrm{Pz}$ and $\mathrm{Cz}$ scalp locations (within-subject factor) did not reveal any between-subject effects or interactions (caregiving and pain factors), or in relation to P300 amplitude or P300 latency. Table 3 presents in detail the results of this analysis (Table 3).

Figure 1 shows the means, standard errors and p-values of the groups, according to the P300 latency and amplitude measurements in the $\mathrm{Fz}, \mathrm{Cz}$ and $\mathrm{Pz}$ channels. No statistical differences between the groups could be seen through performing the one-way ANOVA test. 
Table 2. Comparison between the domains of Addenbrooke's Cognitive Examination Revised and the Brief Cognitive Screening Battery, according to the caregiving and chronic pain factors.

\begin{tabular}{|c|c|c|c|c|c|c|c|}
\hline & \multicolumn{2}{|c|}{ Chronic pain } & \multicolumn{2}{|c|}{ Absence of pain } & \multirow{2}{*}{$\begin{array}{l}\text { p-value } \\
\text { Pain and } \\
\text { no pain* }\end{array}$} & \multirow{2}{*}{$\begin{array}{l}\text { p-value } \\
\text { Caregiving } \\
\text { and no } \\
\text { caregiving* }\end{array}$} & \multirow{2}{*}{$\begin{array}{l}\mathrm{p} \text {-value } \\
\text { Caregiving } \\
\text { and pain* }\end{array}$} \\
\hline & $\begin{array}{c}\text { Caregivers } \\
\quad(n=44)\end{array}$ & $\begin{array}{c}\text { Non-caregivers } \\
\quad(n=44)\end{array}$ & $\begin{array}{l}\text { Caregivers } \\
\quad(n=31)\end{array}$ & $\begin{array}{l}\text { Non-caregivers } \\
\quad(n=30)\end{array}$ & & & \\
\hline \multicolumn{8}{|l|}{ ACE-R domains } \\
\hline Attention/orientation & $13.02 \pm 2.23$ & $13.70 \pm 2.58$ & $14.32 \pm 2.18$ & $14.03 \pm 2.65$ & 0.045 & 0.627 & 0.231 \\
\hline Memory & $13.09 \pm 5.33$ & $14.52 \pm 5.85$ & $16.22 \pm 5.73$ & $14.46 \pm 6.61$ & 0.116 & 0.867 & 0.104 \\
\hline Fluency & $5.30 \pm 2.47$ & $5.80 \pm 2.84$ & $6.83 \pm 3.01$ & $6.06 \pm 3.20$ & 0.665 & 0,775 & 0.183 \\
\hline Language & $17.97 \pm 4.70$ & $17.72 \pm 5.36$ & $20.16 \pm 4.76$ & $18.30 \pm 5.89$ & 0.112 & 0.223 & 0.351 \\
\hline Visual-spatial skills & $9.43 \pm 3.45$ & $10.00 \pm 3.22$ & $11.22 \pm 3.67$ & $10.96 \pm 3.36$ & 0.017 & 0.786 & 0.469 \\
\hline Total score & $58.84 \pm 15.24$ & $61.77 \pm 17.00$ & $68.77 \pm 16.12$ & $63.83 \pm 19.02$ & 0.033 & 0.720 & 0.720 \\
\hline \multicolumn{8}{|l|}{ BCSB domains } \\
\hline Incidental & $4.34 \pm 1.86$ & $4.76 \pm 2.76$ & $4.4 \pm 1.63$ & $4.46 \pm 1.83$ & 0.701 & 0.434 & 0.568 \\
\hline Immediate & $6.65 \pm 1.61$ & $6.90 \pm 1.93$ & $7.23 \pm 1.71$ & $6.26 \pm 1.65$ & 0.910 & 0.221 & 0.040 \\
\hline Learning & $7.52 \pm 2.05$ & $7.79 \pm 1.69$ & $8.26 \pm 1.77$ & $6.96 \pm 1.90$ & 0.899 & 0.102 & 0.014 \\
\hline 5 minutes & $6.25 \pm 2.91$ & $6.76 \pm 2.68$ & $7.90 \pm 2.02$ & $6.70 \pm 2.50$ & 0.072 & 0.436 & 0.051 \\
\hline Recognition & $9.00 \pm 1.16$ & $9.11 \pm 1.38$ & $9.40 \pm 1.32$ & $8.90 \pm 1.58$ & 0.797 & 0.423 & 0.041 \\
\hline
\end{tabular}

*Two-way ANOVA; ACE-R: Addenbrooke's Cognitive Examination Revised; BCSB: Brief Cognitive Screening Battery.

Table 3. Result from the repeated-measurement ANOVA test to compare the groups according to P300 latency and amplitude in the locations Fz, Pz and $\mathrm{Cz}$.

\begin{tabular}{lccc}
\hline Comparison & df & F & p-value \\
\hline $\begin{array}{l}\text { Latency (Fz, Pz and Cz) } \\
\text { and caregiving }\end{array}$ & 1.652 & 0.674 & 0.484 \\
$\begin{array}{l}\text { Latency (Fz, Pz and Cz) } \\
\text { and pain }\end{array}$ & 1.652 & 0.525 & 0.558 \\
$\begin{array}{l}\text { Latency (Fz, Pz and Cz) } \\
\text { and caregiving and pain }\end{array}$ & 1.652 & 1.413 & 0.246 \\
$\begin{array}{l}\text { Amplitude (Fz, Pz and Cz) } \\
\text { and caregiving }\end{array}$ & 1.739 & 0.414 & 0.633 \\
$\begin{array}{l}\text { Amplitude (Fz,Pz and Cz) } \\
\text { and pain }\end{array}$ & 1.739 & 1.027 & 0.352 \\
$\begin{array}{l}\text { Amplitude (Fz, Pz and Cz) } \\
\text { and caregiving and pain }\end{array}$ & 1.739 & 1.002 & 0.360 \\
\hline $\begin{array}{l}\text { Fz: frontal scalp region:Cz: central scalp region:Pz: parietal scalp region } \\
\end{array}$
\end{tabular}

\section{DISCUSSION}

The results showed that, in general, the pain-free caregiver group presented better cognitive performance than the group with chronic pain, with significantly better scores in some domains of the ACE-R instrument and in the total score. However, no differences in P300 amplitude or P300 latency were found between the groups.

\section{Cognitive performance}

Our findings demonstrated that chronic pain might affect some cognitive functions (attention/orientation and visual-spatial skills), as measured using the ACE-R. These results appear to be in accordance with previous data in the literature showing that patients with chronic pain performed worse than did pain-free participants ${ }^{24,25}$. Furthermore, a negative relationship has been found between pain and cognitive functioning in middle-age adults ${ }^{26}$ and participants aged over 70 years $^{27}$.

Studies have shown that one of the main factors giving rise to worse cognitive performance among participants with chronic pain is the interference of pain in attention resources ${ }^{3,28,29}$. Continuous pain may trigger a negative effect on some brain regions, through altering synaptic connectivity and causing inhibition of cognitive control ${ }^{1,3}$. Therefore, pain competes with the stimuli needed for attention, which results in impairment of the performance of cognitive tasks ${ }^{2,28}$.

Regarding memory, there were no statistical differences between the groups with and without chronic pain. These results diverge from the data in the literature. Some previous studies have indicated that participants with chronic pain present worse results in memory tests, especially with regard to working and episodic memory, compared with painfree controls ${ }^{25,26,27}$. From a meta-analysis on 23 studies, it was concluded that individuals with chronic pain presented worse performance in working memory than did a control group ${ }^{30}$.

In the present study, two-way ANOVA revealed a significant interaction effect between the caregiving and pain factors, on cognitive processing assessed using the BCSB. Thus, these data give rise to the understanding that the act of caregiving contributed towards preserving cognitive function in this sample. Some authors have concluded that the need to perform complex tasks relating to daily caregiving can contribute to maintenance of cognitive function in the 

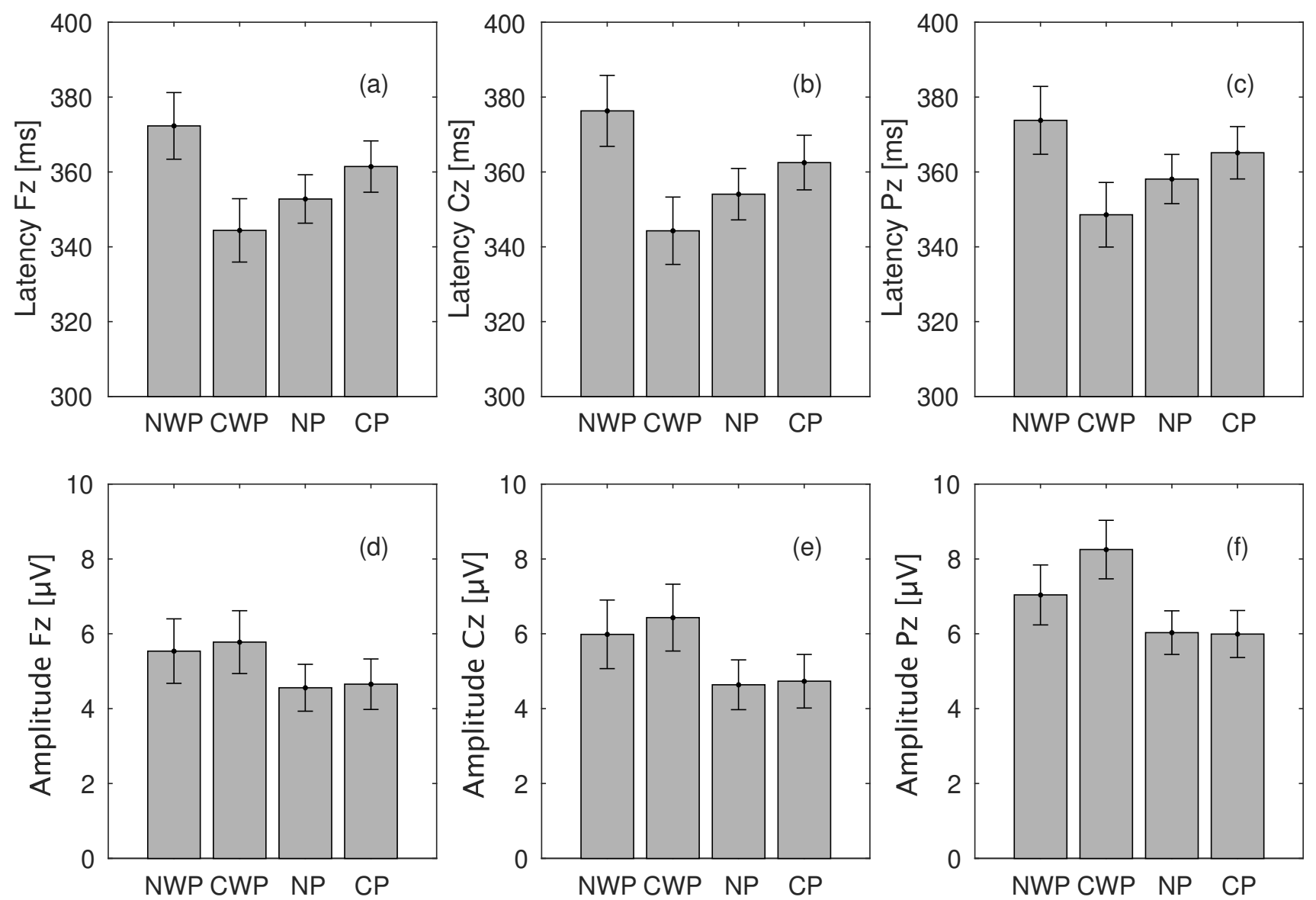

CP: caregivers with chronic pain $(n=44)$; NP: non-caregivers with chronic pain $(n=44)$; CWP: caregivers without pain ( $n=31)$; NWP: non-caregivers without pain $(n=30)$. Repeated-measurement ANOVA test.

Figure 1. Comparison between the groups, according to the P300 latency and amplitude measurements in the Fz, Cz and Pz channels, through means and standard errors.

caregiver $^{31,32}$. However, this hypothesis could not be verified in the present study due to interference from the pain factor.

Another important point that we observed was that among the participants with chronic pain, there was no statistical difference in cognitive performance between caregivers and non-caregivers. This may have been due to possible interaction between the neural systems involved in cognition and the pain modulation system. This interaction between structures impairs the speed at which information is processed in the brain ${ }^{2}$. Continuous pain can also cause cognitive interference in caregivers, even if they are performing complex activities to deliver care. Thus, chronic pain can be a detrimental factor with regard to attention and memory components and consequently can cause cognitive impairment.

There were no studies in the literature that could confirm the abovementioned hypotheses. Thus, future studies are necessary in order to compare results. This study presents important and innovative results, given that the data in the literature on the influences of caring on the physical and psychological health of elderly caregivers living in the community is inconclusive $^{6,31}$. In addition, studies on cognitive performance in the elderly community with chronic pain are still scarce.
A study conducted in the United States among 916 elderly women showed that caregivers performed better in tests on working memory and processing speed than did non-caregiver participants ${ }^{32}$. However, a longitudinal study conducted on a group of Alzheimer's disease caregivers and a group of non-caregivers demonstrated that caregivers performed worse in processing speed tests than non-caregivers and also had a higher rate of cognitive decline ${ }^{33}$. Moreover, it should be emphasized that the instruments used to evaluate cognition present great diversity, which may be a factor that makes comparisons difficult.

\section{Cognitive processing}

In the present study we also used event-related potentials elicited through auditory stimuli during an oddball task to analyze differences between groups regarding neurophysiological correlates of cognitive processing. This type of task requires selection of sound stimuli and an objective electrophysiological indicator of cognitive function ${ }^{34,35}$. In particular, P300 amplitudes and latencies were analyzed since it has been demonstrated that the P300 component may reflect processes involved in stimulus processing and categorization during decision 
making. Moreover, longer P300 latencies and reduced P300 amplitudes have been associated with cognitive dysfunction ${ }^{23,34}$.

Recently, some studies have used measurements based on EEGs as an instrument for brain evaluation in individuals with chronic pain. A recent systematic review showed that EEG analyses are objective and relatively simple tools for identifying specific characteristics of brain conditions in individuals with chronic pain. In the majority of studies, spectral power aspects have been analyzed in frequency bands (alpha and theta) and event-related potentials. However, there is great heterogeneity across studies regarding the technical protocols adopted ${ }^{36}$.

In our study, we did not find any statistical differences between groups, either in P300 amplitude or in P300 latency. A recent study showed that patients with chronic low-back painhadlower P300 amplitudes, decreased attention, impaired decision-making and reduced working memory capacity, compared with a control group ${ }^{37}$. Furthermore, patients with migraine showed lower P300 amplitudes than healthy controls, thus suggesting the existence of dysfunction of cognitive processing associated with migraine ${ }^{38}$.

A previous study comparing the cognitive performance of individuals with chronic pain or episodic pain, in relation to a control group, presented divergent data in which it was not possible to observe any statistical differences in the amplitude of P300 between these groups ${ }^{39}$.

Another study used P300 amplitude to investigate the effects of chronic pain on attentional processing by using a probe task. Fourteen chronic pain patients and thirty age and educationmatched healthy controls were investigated. An attentional capacity probe task was used, in which the difficulty level was manipulated. This resulted in an easy and a difficult condition, while task-irrelevant visual probes were also presented. According to the authors, the results may imply that, instead of attentional capacity, allocation of attentional resources is the deficient aspect in pain patients ${ }^{40}$. The results might be associated with a model of hypervigilance among patients with chronic pain, since hypervigilance can make patients more sensitive to distraction, especially in relation to new stimuli ${ }^{40,41}$.
Our study evaluated elderly caregivers living in the community. This topic is relatively new, since there are an increasing number of elderly people caring for another elderly person in the same house. Evaluation of these subjects is important for enabling development of healthcare strategies, mainly because of the gaps in knowledge regarding this matter among elderly caregivers. Furthermore, chronic pain interferes in the performance of activities of daily living and negatively influences the care that is provided to the other elderly individual. Moreover, it predisposes the caregiver to cognitive alterations, greater overload, worse quality of life and depression: factors that compromise the behavioral and social skills of the elderly individual.

One limitation of the present study was caregiver profile selection bias. Participants who provided different degrees of care were selected, thus making it difficult to standardize the burden of the care given. Furthermore, the sample size was small and variables such as the participants' use of medications, depression symptoms and sleep disorders were not controlled for.

One important aspect of the present study was that it evaluated elderly people's cognition, among participants with and without chronic pain, and tit ascertained whether the act of caring had an effect on the performance and cognitive processing of this population. In general, it was observed that pain-free individuals presented better performance. The groups without chronic pain demonstrated significantly higher values in the ACE-R cognitive instrument, compared with the groups with chronic pain.

\section{ACKNOWLEDGEMENTS}

Publication of this article was supported by the Coordenação de Aperfeiçoamento de Pessoal de Nível Superior (CAPES), Conselho Nacional de Desenvolvimento Científico e Tecnológico (CNPq) and Fundação de Amparo à Pesquisa do Estado de São Paulo (FAPESP).

\section{References}

1. Simons LE, Elman I, Borsook D. Psychological processing in chronic pain: A neural systems approach. Neurosci Biobehav Rev. 2014 Feb;39:61-78. https://doi.org/10.1016/j. neubiorev.2013.12.006

2. Moriarty O, McGuire BE, Finn DP. The effect of pain on cognitive function: A review of clinical and preclinical research. Prog Neurobiol. 2011 Mar;93(3):385-404. https://doi.org/10.1016/j. pneurobio.2011.01.002

3. van der Leeuw G, Eggermont LHP, Shi L, Milberg WP, Gross AL, Hausdorff JM, et al. Pain and cognitive function among older adults living in the community. J Gerontol A Biol Sci Med Sci. 2016 Mar;71(3):398-405. https://doi.org/10.1093/gerona/glv166

4. Figueiredo CS, Assis MG, Silva SLA, Dias RC, Mancini MC, Figueiredo $\mathrm{CS}$, et al. Functional and cognitive changes in community- dwelling elderly: Longitudinal study. Brazilian J Phys Ther. 2013 May-Jun;17(3):297-306. https://doi.org/10.1590/S141335552012005000094

5. Hjelm CM, Broström A, Riegel B, Arrestedt K, Strömberg A. The association between cognitive function and self-care in patients with chronic heart failure. Heart Lung. Mar-Apr 2015;44(2):113-9. https://doi.org/10.1016/j.hrtlng.2014.12.003

6. Roth DL, Fredman L, Haley WE. Informal caregiving and its impact on health: a reappraisal from population-based studies. Gerontologist. 2015 Apr;55(2):309-19. https://doi.org/10.1093/geront/gnu177

7. Luchesi BM, Souza ÉN, Gratão ACM, Gomes GA de O, Inouye K, Alexandre T da S, et al. The evaluation of perceived stress and associated factors in elderly caregivers. Arch Gerontol Geriatr. NovDec 2016;67:7-13. https://doi.org/10.1016/j.archger.2016.06.017 
8. Aguilar V, Peña Z, Ponce CG. Overload and pain in perceived caregivers of dependent elder. Enfermería Glob. 2012 Jul;27:166-71. Available at: http://scielo.isciii.es/pdf/eg/v11n27/en_docencia4.pdf

9. Loureiro L de SN, Fernandes MGM, Nóbrega MML Da, Rodrigues RAP. Sobrecarga em cuidadores familiares de idosos: associação com características do idoso e demanda de cuidado. Rev Bras Enferm. 2014;67(2):227-32. https://dx.doi.org/10.5935/0034-7167.20140030

10. Tomomitsu MRSV, Perracini MR, Neri AL. Fatores associados à satisfação com a vida em idosos cuidadores e não cuidadores. Cien Saude Colet. 2014 Aug;19(8):3429-40. https://dx.doi. org/10.1590/1413-81232014198.13952013

11. Bianchi M, Flesch LD, Alves EVC, Batistoni SST, Neri AL. Zarit Burden Interview psychometric indicators applied in older people caregivers of other elderly. Rev Lat Am Enfermagem. 2016 Nov;24:e2835. https://doi.org/10.1590/1518-8345.1379.2835

12. Faleiros AH, Santos CA, Martins CR, Astrazione De Holanda R. Os desafios do cuidar: revisão bibliográfica, sobrecargas e satisfações do cuidador de idosos. Janus. 2018;12(6). Available from: http://fatea. br/seer/index.php/janus/article/viewFile/1793/1324

13. Lino VTS, Pereira SRM, Camacho LAB, Filho STR, Buksman S. Adaptação transcultural da Escala de Independência em Atividades da Vida Diária (Escala de Katz). Cad Saúde Pública. 2008;24(1):10312. https://dx.doi.org/10.1590/S0102-311X2008000100010

14. Santos RL, Virtuoso JS. Confiabilidade da versão da escala brasileira da escala de atividades instrumentais da vida diária. RBPS. 2008;21(4):290-6. https://doi.org/10.5020/575

15. Merskey H, Bogduk N. Classification of Chronic Pain. 1994. Available from: https://www.iasp-pain.org/PublicationsNews/Content.aspx?lt emNumber $=1957 \&$ navltemNumber $=677$

16. American Clinical Neurophysiology Society. Guideline 8: Guidelines for recording clinical EEG on digital media.J Clin Neurophysiol. 2006 Apr;23(2):122-4. https://doi.org/10.1097/00004691-200604000-00009

17. Polich J. Meta-analysis of P300 normative aging studies. Psychophysiology. 1996 Jul;33(4):334-53. https://doi. org/10.1111/j.1469-8986.1996.tb01058.x

18. Nitrini R, Helena Lefèvre B, Mathias SC, Caramelli P, Carrilho PEM, Sauaia N, et al. Testes neuropsicológicos de aplicação simples para o diagnóstico de demência. Arq Neuro-Psiquiatr. 1994 Dec;52(4):45765. https://doi.org/10.1590/S0004-282X1994000400001

19. Nitrini R, Caramelli P, Herrera E, Porto CS, Charchat-Fichman $\mathrm{H}$, Carthery MT, et al. Performance of illiterate and literate nondemented elderly subjects in two tests of long-term memory. J Int Neuropsychol Soc. 2004 Jul;10(4):634-8. https://doi.org/10.1017/ S1355617704104062

20. César KG, Yassuda MS, Porto FHG, Brucki SMD, Nitrini R. Addenbrooke's cognitive examination-revised: normative and accuracy data for seniors with heterogeneous educational level in Brazil. Int Psychogeriatrics. 2017 Aug;29(08):1345-53. https://doi. org/10.1017/S1041610217000734

21. Sousa FAEF, Pereira LV, Cardoso R, Hortense P, Hortense P. Multidimensional pain evaluation scale. Rev Lat Am Enfermagem. 2010 Feb;18(1):03-10. https://doi.org/10.1590/S010411692010000100002

22. Almeida O, Almeida SA. Confiabilidade da versão brasileira da Escala de Depressão em Geriatria (GDS) versão reduzida. Arq Neuro-Psiquiatr. 1999;57(2-B):421-6. https://doi.org/10.1590/S0004282X1999000300013

23. Polich J. Updating P300: An integrative theory of P3a and P3b. Clin Neurophysiol. 2007 Oct;118(10):2128-48. https://doi.org/10.1590/ S0004-282X1999000300013

24. Melkumova KA, Podchufarova EV, Yakhno NN. Characteristics of Cognitive Functions in Patients with Chronic Spinal Pain. Neurosci Behav Physiol. 2011 Jan;41(1):42-6. https://doi.org/10.1007/s11055010-9376-3
25. Oosterman JM, Derksen LC, van Wijck AJM, Veldhuijzen DS, Kessels RPC. Memory functions in chronic pain. Clin J Pain. 2011 Jan;27(1):70-5. https://doi.org/10.1097/AJP.0b013e3181f15cf5

26. Tomey K, Greendale GA, Kravitz HM, Bromberger JT, Burns JW, Dugan SA, et al. Associations between aspects of pain and cognitive performance and the contribution of depressive symptoms in mid-life women: a cross-sectional analysis. Maturitas. 2015 Jan;80(1):106-12. https://doi.org/10.1016/j.maturitas.2014.10.013

27. Scemes E, Zammit AR, Katz MJ, Lipton RB, Derby CA. Associations of cognitive function and pain in older adults Int J Geriatr Psychiatry. 2017 Jan;32(1):118-20. https://doi.org/10.1002/gps.4580

28. Eccleston C, Crombez G. Pain demands attention: A cognitiveaffective model of the interruptive function of pain. Psychol Bull. 1999 May;125(3):356-66. https://doi.org/10.1037/00332909.125.3.356

29. Legrain V, Damme S Van, Eccleston C, Davis KD, Seminowicz DA, Crombez G. A neurocognitive model of attention to pain: behavioral and neuroimaging evidence. Pain. 2009 Aug;144(3):230-2. https://doi. org/10.1016/j.pain.2009.03.020

30. Berryman C, Stanton TR, Bowering JK, Tabor A, McFarlane A, Moseley LG. Evidence for working memory deficits in chronic pain: a systematic review and meta-analysis. Pain. 2013 Aug;154(8):118196. https://doi.org/10.1016/j.pain.2013.03.002

31. Brown RM, Brown SL. Informal caregiving: a reappraisal of effects on caregivers. Soc Issues Policy Rev. 2014 Jan;8(1):74-102. http://doi. org/10.1111/sipr.12002

32. Bertrand RM, Saczynski JS, Mezzacappa C, Hulse M, Ensrud K, Fredman L. Caregiving and cognitive function in older women: evidence for the healthy caregiver hypothesis. J Aging Health. 2012 Feb;24(1):48-66. http://doi.org/10.1177/0898264311421367

33. Vitaliano PP, Zhang J, Young HM, Caswell LW, Scanlan JM, Echeverria D. Depressed mood mediates decline in cognitive processing speed in caregivers. Gerontologist. 2009 Feb;49(1):12-22. http://doi. org/10.1093/geront/gnp004

34. van Dinteren R, Arns M, Jongsma MLA, Kessels RPC. P300 Development across the lifespan: a systematic review and metaanalysis. PLoS One. 2014 Feb;9(2):e87347. http://doi.org/10.1371/ journal.pone.0087347

35. Leocani L, Comi G. Clinical neurophysiology of multiple sclerosis. Handb Clin Neurol. 2014;122:671-9. http://doi.org/10.1016/B978-0444-52001-2.00028-5

36. Pinheiro ESS, Queirós FC, Montoya P, Santos CL, Nascimento $\mathrm{MA}$, Ito $\mathrm{CH}$, et al. Electroencephalographic patterns in chronic pain: a systematic review of the literature. PLoS One. 2016 Feb;11(2):e0149085. http://doi.org/10.1371/journal.pone.0149085

37. Anatskaia L, Svinkouskaya T, Zabarovski V. Auditory p300 eventrelated evoked potentials and spectral electroencephalography analysis in monitoring response of recurrent low back pain to manipulative therapy.J Neurol Sci. 2017 Oct;381(Supplement):165. https://doi.org/10.1016/j.jns.2017.08.483

38. Titlic M, Mise NI, Pintaric I, Rogosic V, Vanjaka-Rogosic L, Mihalj M, et al. The event-related potential P300 in patients with migraine. Acta Inform Med. 2015 Dec;23(6):339-42. http://doi.org/10.5455/ aim.2015.23.339-342

39. Demirci S, Savas S. The auditory event related potentials in episodic and chronic pain sufferers. Eur J Pain. 2002;6(3):239-44. http://doi. org/10.1053/eujp.2001.0342

40. Veldhuijzen DS, Kenemans JL, Van Wijck AJM, Olivier B, Kalkman CJ, Volkerts ER. Processing capacity in chronic pain patients: A visual event-related potentials study. Pain. 2006 Mar;121(1-2):60-8. http:// doi.org/10.1016/j.pain.2005.12.004

41. Crombez G, Van Damme S, Eccleston C. Hypervigilance to pain: an experimental and clinical analysis. Pain. $2005 \mathrm{Jul} ; 116(1-2): 4-7 . \mathrm{http}: / /$ doi.org/10.1016/j.pain.2005.03.035 